\title{
1 Overview on COVID-19 outbreak indicators across Brazilian 2 federative units
}

4 Elvira Maria Guerra-Shinohara ${ }^{1,2,3,4^{*}}$, Simone Schneider Weber ${ }^{1,5,6}$, Clóvis Paniz ${ }^{7}$ Guilherme 5 Wataru Gomes ${ }^{4}$, Eduardo Jun Shinohara ${ }^{8}$, Tiago Borges Ribeiro Gandra ${ }^{9}$, Indiara Correia 6 Pereira $^{2}$, Karine Gomes Jarcem ${ }^{3}$, Renato Ferreira de Almeida Zanre ${ }^{5}$ Acácia Gimenez 7 Barreto ${ }^{5}$, Alessandro Diogo De Carli ${ }^{5,10}$

9 1. Faculdade de Ciências Farmacêuticas, Alimentos e Nutrição (FACFAN), Universidade Federal de 10 Mato Grosso do Sul, Campo Grande, MS, Brazil

2. Programa de Pós-Graduação Stricto Sensu em Ciências Farmacêuticas, Faculdade de Ciências Farmacêuticas, Alimentos e Nutrição, Universidade Federal de Mato Grosso do Sul, Campo Grande, MS, Brazil

3. Programa de Pós-Graduação Stricto Sensu em Enfermagem, Instituto Integrado de Saúde, Universidade Federal de Mato Grosso do Sul, Campo Grande, MS, Brazil

4. Programa de Pós-Graduação Stricto Sensu em Farmácia (Fisiopatologia e Toxicologia), Faculdade de Ciências Farmacêuticas da Universidade de São Paulo, SP, Brazil

5. Programa de Pós-Graduação Stricto Sensu em Saúde da Família, Universidade Federal de Mato Grosso do Sul, Campo Grande, MS, Brazil

6. Instituto de Ciências Exatas e Tecnologia, Universidade Federal do Amazonas, Itacoatiara, AM, Brazil

7. Departamento de Análises Clínicas e Toxicológicas, Centro de Ciências da Saúde, Universidade Federal de Santa Maria, Santa Maria, RS, Brazil

8. Companhia Ambiental do Estado de São Paulo, CETESB, SP, Brazil

9. Instituto Federal de Educação Ciência e Tecnologia do Rio Grande do Sul, Rio Grande, RS, Brazil

10. Faculdade de Odontologia, Universidade Federal de Mato Grosso do Sul, Campo Grande, MS, Campo Grande, Brazil

32 E-mail: elvira.guerra@ufms.br or emguerra@usp.br (EMGS) 


\section{Abstract}

35 Background. The 2019 coronavirus disease pandemic (COVID-19) spread rapidly across

36 Brazil. The country has 27 federative units, with wide regional differences related to climate,

37 lifestyle habits, socioeconomic characteristics and population density. Therefore, we aimed

38 to document and monitor the increase in COVID-19 cases across each federative unit in

39 Brazil, by tracking its progression from inception to 15 May 2020. Methods. Observational

40 study. Results. The first confirmed COVID-19 case in the country was notified in São Paulo

41 on 26 February, while the first death occurred on 17 March, in Rio de Janeiro. Since then,

42 there has been a dramatic increase in both confirmed cases and deaths from the disease.

43 São Paulo, in the Southeast region, was initially considered the COVID-19 epidemic

44 epicentre in Brazil. However, 10 states in the North and Northeast regions were ranked

45 among the 14 highest incidences (over 100 cases per 100,000 people) observed on 15 May.

46 Higher incidence rates (>100 cases per 100,000) were associated to higher rates of

47 inadequate water supply and sewerage (OR, $5.83(95 \% \mathrm{Cl}, 1.08-29.37, \mathrm{P}=0.041))$. North

48 and Northeast states with the highest social vulnerability index scores had higher increases

49 in the incidence rate between 14 April and 15 May. States with medium human development

50 index (HDI) showed higher incidence increases from 14 April to 15 May, being seven of them

51 with ratios in the range from 27.49 to 63.73 times. Conclusion. Spreading of COVID-19 in

52 Brazil differs across both regions and federative units, being influenced by different 53 socioeconomic contexts.

Keywords: coronavirus, SARS-CoV-2, epidemic, public health, nursing, pharmaceutical 
medRxiv preprint doi: https://doi.org/10.1101/2020.06.02.20120220; this version posted June 5, 2020. The copyright holder for this preprint (which was not certified by peer review) is the author/funder, who has granted medRxiv a license to display the preprint in perpetuity.

\section{Introduction}

71 This year 2020 will go down in world history due to the coronavirus disease of 2019

72 (COVID-19) pandemic. The first suspected case of COVID-19 was reported in Wuhan, the 73 capital of Hubei Province, China, on 1 December 2019 [1-3]. The peak of the epidemic in

74 China occurred on 19 February 2020, and a month later the number of deaths in China 75 reached 3,242 out of a total of 81,174 confirmed cases [4].

76 In a health crisis unprecedented in recent history, cases of severe acute respiratory 77 syndrome by coronavirus 2 (SARS-CoV-2) crossed the country's borders and rapidly spread across the world, leading to the official declaration of a global pandemic and public health emergency by the World Health Organization (WHO) in 11 March $2020[5,6]$.

Person-to-person transmission of SARS-CoV-2 from asymptomatic patients was first documented in Germany and Vietnam clusters during early February 2020 [7, 8]. However, Wu and McGoogan (2020) described that $81 \%$ of initial patients notified in China experienced only mild disease, which could have contributed to an asymptomatic transmission [9]. In addition, recent reports have pointed out that virus incubation may be longer than the 14 days period used by the WHO to guide quarantine policies $[10,11]$. Taken together, these factors are undoubtedly contributing to the rapid spread of SARS-CoV-2 over the world [12-14].

Since early March 2020, a rapid increase in the number of cases in Italy, Spain,

France, Germany and Iran has been observed. According to data from WHO (situation report 123) on 22 May 2020, most reported cases occurred in the United States of America (1,525,186 cases with 91,527 deaths), the Russian Federation (326,448 cases with 3,249 deaths) followed by Brazil in third position [15].

In Brazil, the first confirmed case of COVID-19 was notified in São Paulo state on 26

94 February, while the first death was registered on 17 March 2020 in Rio de Janeiro state.

95 Since then, the incidence of COVID-19 has increased very rapidly in the country, reaching a 
medRxiv preprint doi: https://doi.org/10.1101/2020.06.02.20120220; this version posted June 5, 2020. The copyright holder for this preprint (which was not certified by peer review) is the author/funder, who has granted medRxiv a license to display the preprint in perpetuity.

All rights reserved. No reuse allowed without permission.

96 total of 330,890 confirmed cases with 21,048 deaths, by the cut-off date for data compilation

97 in this study, 22 May 2020 [16].

98 In this context, epidemiological studies conducted early in the course of an epidemic

99 are important to guide public health decision-making. Monitoring numbers of COVID-19

100 cases, deaths, as well as regional differences in incidence, is critical for understanding

101 community risks and making decisions about strategic allocation of health care resources

102 and the control of social distancing during the disease outbreak. Thus, the aim of this study

103 was to document and monitor the increase of COVID-19 cases across each federative unit in

104 Brazil, by following the progression of notified cases from inception to 15 May 2020, as well

105 as their determinants and health indicators.

106

107 Material and Methods

108 Study Design

109 This is an observational study that tracked data on notified cases of COVID-19 in

110 Brazil, from inception to 15 May 2020.

112 Data collection

113 Data on the numbers of both COVID-19 cases and deaths from the disease were 114 obtained from the official website of the Ministry of Health of Brazil, from 14 April 2020 115 onwards [16]. When the data from the Brazilian government website were consulted, care 116 was taken to select the date of the first notification of COVID-19 and the data on 14 April.

117 From that date, a daily follow-up of cases was conducted in each federative unit until 15 May 1182020.

119 Sociodemographic data (population and number of elderly people) by cities and states 120 were estimated by the Brazilian Institute of Geography and Statistics (IBGE) based on the 
medRxiv preprint doi: https://doi.org/10.1101/2020.06.02.20120220; this version posted June 5, 2020. The copyright holder for this preprint (which was not certified by peer review) is the author/funder, who has granted medRxiv a license to display the preprint in perpetuity.

All rights reserved. No reuse allowed without permission.

121 index-date of 1 July 2019, from the last census conducted in Brazil in 2010 [17]. Per capita

122 income was extracted from the demographic census conducted in 2010 [18].

123 Data on health determinants, such as percentage of inadequate water supply and 124 sewerage, and the number of hospital beds and intensive treatment units, were obtained 125 from DATASUS, the IT Department of the Brazilian Unified Health System, and IBGE [18, 126 19]. In addition, social isolation rates were obtained from Inloco website [20].

127 The incidence rate of COVID-19 was obtained based on the estimated population of 128 each federative unit in 2019 and it was presented as cases per 100,000. The case fatality was calculated and presented as a percentage.

130 The Human Development Index (HDI) scores were obtained from the Brazilian Atlas of 131 Human Development, produced by United Nations Development Program (UNDP), Institute 132 of Applied Economic Research (IPEA) and João Pinheiro Foundation [21]. HDI is a 133 development indicator that aggregates economic data from the per capita gross domestic 134 product with other data related to education [adult literacy rate and schooling (combined 135 primary, secondary, and higher education)] and health (mean life expectancy at birth). HDI scores can range from 0 to 1 , and the 27 Brazilian federative units are grouped into four 137 development categories, depending on their HDI score: very high for $\mathrm{HDI} \geq 0.800$, high from 1380.700 to 0.799 , average from 0.550 to 0.699 and low when HDI is below 0.550 [21].

139 The Social Vulnerability Index (SVI) was developed by IPEA. SVI scores were 140 calculated based on the 2010 Brazil census variables. This tool is particularly useful for 141 emergency response planners and public health authorities, as it can identify and map 142 communities most likely to need support before, during, and after a hazardous event. SVI 143 scores can vary from 0 to 1 , with higher values associated to higher social vulnerability. SVI 144 scores for each municipality were classified in five levels: very low, from 0 to 0.200 ; low, from 1450.201 to 0.300 ; medium, from 0.301 to 0.400 ; high, from 0.401 to 0.500 ; and very high, 146 above 0.501 to 1 [22]. 
medRxiv preprint doi: https://doi.org/10.1101/2020.06.02.20120220; this version posted June 5, 2020. The copyright holder for this preprint (which was not certified by peer review) is the author/funder, who has granted medRxiv a license to display the preprint in perpetuity. All rights reserved. No reuse allowed without permission.

\section{Ethics}

In addition, data were organized and made available at a geospatial data platform called PIE-COVID, which has numerous georeferenced variables of all cases of COVID-19 in Brazilian cities and states [23].

\section{Statistical analyses}

Statistical analyses were performed using SPSS version 22.0 (IBM, USA) and GraphPad Prism ${ }^{\mathrm{TM}}$ version 5.04 (GraphPad Software, Inc., USA).

Spearman's correlations between COVID-19 incidence on 31 April and SVI, and between incidence ratio (15 May/14 April) and SVI, were calculated for each of the 27 federative units.

Incidence rates of COVID-19 on 15 May were divided into two groups, according to median rate (cut-off point, >100). Water supply and sewerage inadequacy rates (\%) were also categorized in two groups, according to median rate (cut-off point, $\geq 9.0 \%$ ).

The increase in incidence rate over the course of a month was obtained by the ratio between incidence rates registered on 15 May and 14 April 2020. In addition, increases in incidence rates were classified into quartiles ( $1^{\text {st }}$ quartile, 2.83 to $5.94 ; 2^{\text {nd }}$ quartile, 5.95 to $13.38 ; 3^{\text {rd }}$ quartile, 13.39 to 27.48 ; and $4^{\text {th }}$ quartile, 27.49 to 63.73$)$. 
medRxiv preprint doi: https://doi.org/10.1101/2020.06.02.20120220; this version posted June 5, 2020. The copyright holder for this preprint (which was not certified by peer review) is the author/funder, who has granted medRxiv a license to display the preprint in perpetuity. All rights reserved. No reuse allowed without permission.

174

175

176

\section{Results} 1 and 2.

The chi-square test or the likelihood ratio were used to analyse frequencies of categorical variables, with a significance level of $\alpha=0.05$.

The first case of COVID-19 in Brazil was reported in São Paulo city on 26 February, a person who had returned from a trip to Italy some days before. On this date, Brazil became the first country to report a case of COVID-19 in Latin America.

Among the capitals of Brazilian federative units, 25 out of 27 had cases of COVID-19 in March. Only the capitals of the states of Piauí (Teresina) and Tocantins (Palmas) reported cases in April. In Piauí, two cities had cases in March (Parnaíba and São José do Divino), and in Tocantins only Araguaína had a case on 27 March 2020.

In this study, we decided to present data according to the five politic regions of Brazil: North, Northeast, Southeast, South and Midwest.

North region consists of seven states: Rondônia (RO), Acre (AC), Amazonas (AM), Roraima (RR), Pará (PA), Amapá (AP), and Tocantins (TO). The first case of COVID-19 recorded in this region was on 15 March 2020 in AM, the state with the worst social vulnerability index (SVI) and one of the worst Human Development Index (HDI) scores among North states.

Furthermore, AM together with the small state of AP registered on 30 April 2020 the highest incidence of COVID-19 in the North. On 15 May 2020, the incidence rate of COVID19 in these states (AM, 443.76; and AP, 429.21) was more than three times that of São Paulo (127.13), Federal District (125.59), and Rio de Janeiro (115.77), Fig 1. The North region had 40,473 cases and 2,762 deaths, ranking third among all five regions. Information about population, health determinants and indicators and about notification of COVID-19 of North region from the beginning of pandemic until 15 May 2020 is shown in Table 1 and Fig 
medRxiv preprint doi: https://doi.org/10.1101/2020.06.02.20120220; this version posted June 5, 2020. The copyright holder for this preprint (which was not certified by peer review) is the author/funder, who has granted medRxiv a license to display the preprint in perpetuity. All rights reserved. No reuse allowed without permission.

201 Figure 1. Incidence rate of COVID-19 (cases per 100,000) and case fatality (\%) in 202 Brazilian federative units on 14 ( $A$ and $B$ ) and 30 (C and D) April 2020; incidence rate of 203 COVID-19 on 15 May 2020 (E); and inadequate water supply and sewerage rates (F), 204 2010. Figure $F$ shows federative units in decreasing order of COVID-19 incidence, 205 according to data from 15 May 2020. AC: Acre, AL: Alagoas, AP: Amapá, AM: Amazonas, BA: Bahia, 206 CE: Ceará, DF: Distrito Federal, ES: Espírito Santos, GO: Goiás, MA: Maranhão, MT: Mato Grosso, MS: Mato 207 Grosso do Sul, MG: Minas Gerais, PA: Pará, PB: Paraíba, PR: Paraná, PE: Pernambuco, PI: Piauí, RJ: Rio de 208 Janeiro, RN: Rio Grande do Norte, RS: Rio Grande do Sul, RO: Rondônia, RR: Roraima, SC: Santa Catarina, SP: 209 São Paulo, SE: Sergipe, TO: Tocantins.

210 
Table 1. Notification of COVID-19 in the North and Northeast regions of Brazil until 15 May 2020

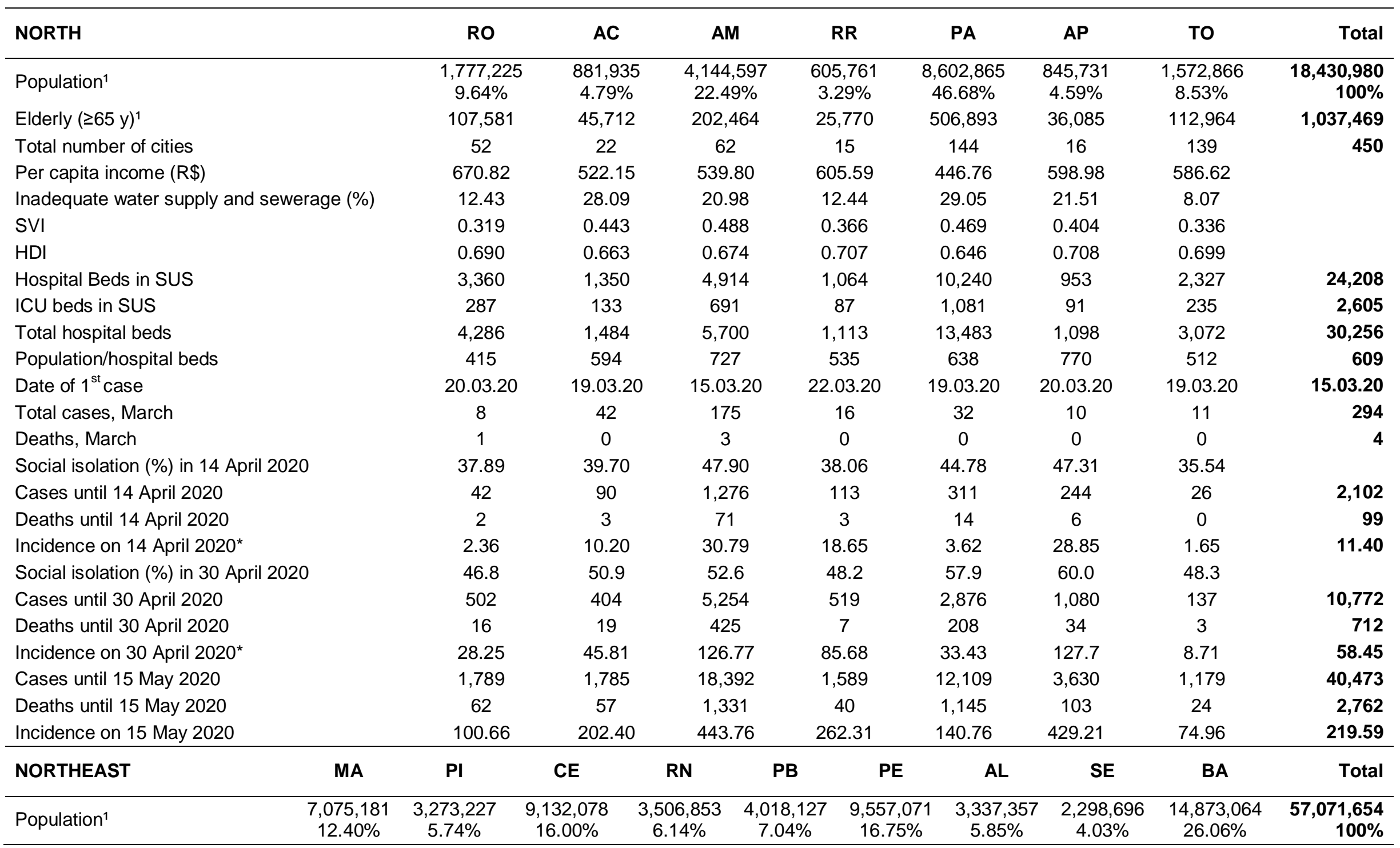


10

\begin{tabular}{|c|c|c|c|c|c|c|c|c|c|c|}
\hline Elderly $(\geq 65 y)^{1}$ & 503,654 & 285,899 & 816,935 & 315,584 & 393,136 & 845,808 & 254,662 & 172,546 & $1,335,027$ & $4,923,251$ \\
\hline Total number of cities & 217 & 224 & 184 & 167 & 223 & 185 & 102 & 75 & 417 & 1,794 \\
\hline Per capita income $(\mathrm{R} \$)$ & 360.34 & 416.93 & 460.63 & 545.42 & 474.94 & 525.64 & 432.56 & 523.53 & 496.73 & \\
\hline $\begin{array}{l}\text { Inadequate water supply and } \\
\text { sewerage (\%) }\end{array}$ & 23.99 & 8.15 & 10.99 & 9.4 & 11.75 & 10.83 & 13.07 & 11.02 & 9.35 & \\
\hline SVI & 0.521 & 0.403 & 0.378 & 0.349 & 0.385 & 0.414 & 0.461 & 0.393 & 0.403 & \\
\hline $\mathrm{IDH}$ & 0.639 & 0.646 & 0.682 & 0.684 & 0.658 & 0.673 & 0.631 & 0.665 & 0.660 & \\
\hline Hospital Beds in SUS & 12,204 & 6,470 & 14,350 & 5,958 & 6,425 & 15,644 & 4,807 & 2,376 & 22,947 & 91,181 \\
\hline ICU beds in SUS & 784 & 392 & 1,243 & 473 & 671 & 1,404 & 488 & 348 & 1,772 & 7,575 \\
\hline Total hospital beds & 13,778 & 7,460 & 18,510 & 7,250 & 8,147 & 20,945 & 5,891 & 3,212 & 28,960 & 114,153 \\
\hline Population/hospital beds & 514 & 439 & 493 & 484 & 493 & 456 & 567 & 716 & 514 & 500 \\
\hline Date of $1^{\text {st }}$ case & 21.03 .20 & 20.03 .20 & 17.03 .20 & 13.03 .20 & 19.03.20 & 12.03 .20 & 08.03 .20 & 15.03 .20 & 06.03 .20 & 06.03 .20 \\
\hline Total cases March & 31 & 18 & 390 & 82 & 17 & 87 & 18 & 19 & 213 & 875 \\
\hline Deaths March & 1 & 4 & 7 & 1 & 0 & 6 & 1 & 0 & 2 & 22 \\
\hline $\begin{array}{l}\text { Social isolation (\%) in } 14 \text { April } \\
2020\end{array}$ & 47.54 & 47.95 & 49.97 & 85.86 & 46.81 & 50.60 & 44.25 & 47.00 & 46.30 & \\
\hline Cases until 14 April 2020 & 479 & 58 & 1911 & 333 & 136 & 1146 & 51 & 45 & 722 & 4,881 \\
\hline Deaths until 14 April 2020 & 32 & 8 & 100 & 17 & 16 & 101 & 4 & 4 & 22 & 304 \\
\hline Incidence on 14 April 2020* & 6.77 & 1.77 & 20.93 & 9.50 & 3.38 & 11.99 & 1.53 & 1.96 & 4.85 & 8.55 \\
\hline $\begin{array}{l}\text { Social isolation (\%) in } 30 \text { April } \\
2020\end{array}$ & 59.6 & 59,0 & 57.9 & 55.7 & 55.3 & 58.5 & - & 53.2 & 52.9 & \\
\hline Cases until 30 April 2020 & 3,190 & 513 & 7,606 & 1,177 & 814 & 6,876 & 1,044 & 447 & 2,851 & 24,518 \\
\hline Deaths until 30 April 2020 & 184 & 24 & 482 & 56 & 62 & 565 & 47 & 12 & 104 & 1,536 \\
\hline Incidence on 30 April 2020* & 45.09 & 15.67 & 83.29 & 33.56 & 20.26 & 71.95 & 31.28 & 19.45 & 19.17 & 42.96 \\
\hline Cases until 15 May 2020 & 10,739 & 1,905 & 22,490 & 2,786 & 3,739 & 16,209 & 3,212 & 2,868 & 8,128 & 72,076 \\
\hline Deaths until 15 May 2020 & 496 & 60 & 1,476 & 122 & 170 & 1,381 & 187 & 50 & 281 & 4,223 \\
\hline Incidence on 15 May 2020 & 151.78 & 58.2 & 246.27 & 79.44 & 93.05 & 169.60 & 96.24 & 124.77 & 54.65 & 126.29 \\
\hline
\end{tabular}

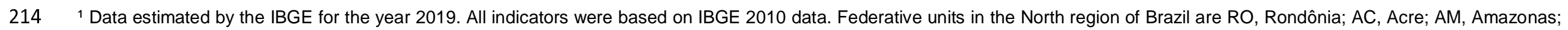

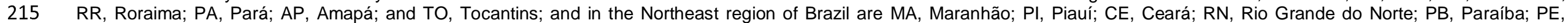

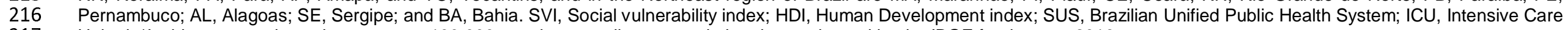
217 United. *Incidence was shown by cases per 100,000 people, according to population data estimated by the IBGE for the year 2019. 
medRxiv preprint doi: https://doi.org/10.1101/2020.06.02.20120220; this version posted June 5, 2020. The copyright holder for this preprint (which was not certified by peer review) is the author/funder, who has granted medRxiv a license to display the preprint in perpetuity.

All rights reserved. No reuse allowed without permission.

219 Figure 2. Data on the incidence of COVID-19 in Brazil until 15 May 2020. (A) Increase in cases over a period of 31 days, using the ratio between incidences per 100,000 on 15 May and 14 April 2020. (B) Association between the incidence of COVID-19 on 15 May (classified into two groups, according to the median) and percentage of inadequate water supply and sewerage (classified into two groups, according to the median). (C) Association between quartiles of increase in the incidence of COVID-19 (incidence ratio) and scores on the Social Vulnerability Index (SVI) (classified into SVI scores $\leq$ "mean" and SVI scores "high" or "very high"). (D) Association between quartiles of increase in the incidence of COVID-19 (incidence ratio) and scores on the Human Development Index (classified into "very high" ( $\geq 0.800)$, "high" (0.700 to 0.799$)$ and "medium" (0.550 to 0.699)). B. Chi-square test. C and D. Likelihood ratio. AC, Acre; AL, Alagoas; AP, Amapá; AM, Amazonas; BA, Bahia; CE, Ceará; DF, Distrito Federal; ES, Espírito Santos; GO, Goiás; MA, Maranhão; MT, Mato Grosso; MS, Mato Grosso do Sul; MG, Minas Gerais; PA, Pará; PB, Paraíba; PR, Paraná; PE, Pernambuco; PI, Piauí; RJ, Rio de Janeiro; RN, Rio Grande do Norte; RS, Rio Grande do Sul; RO, Rondônia; RR, Roraima; SC, Santa Catarina; SP, São Paulo; SE, Sergipe; TO, Tocantins.

Regarding the Northeast region, it is composed of nine states, namely: Maranhão (MA), Piauí (PI), Ceará (CE), Rio Grande do Norte (RN), Paraíba (PB), Pernambuco (PE), Alagoas (AL), Sergipe (SE), and Bahia (BA). The first case in this region was described on 6 March 2020, in BA. As of 15 May 2020, 72,076 cases and 4,223 deaths were reported in Northeast, with CE and PE showing both the highest incidence rates and deaths numbers. Until the last data collection for this study, the cities in Northeast with the highest numbers of confirmed cases and deaths were Fortaleza (CE), Recife (PE), and São Luis (MA). Detailed information on population, health determinants and indicators, and on notification of COVID19 cases in the Northeast region from the first case reported until 15 May 2020 are shown in Table 1.

Southeast region includes the states of Minas Gerais (MG), Espírito Santo (ES), Rio de Janeiro (RJ) and São Paulo (SP), with a large number of municipalities $(1,668)$. Both the first confirmed case and death by COVID-19 registered in this region were also the first ones reported in the country. On 15 May 2020, the southeastern region ranks first in the number of cases $(88,759)$ and deaths $(7,345)$ in Brazil. 
medRxiv preprint doi: https://doi.org/10.1101/2020.06.02.20120220; this version posted June 5, 2020. The copyright holder for this preprint (which was not certified by peer review) is the author/funder, who has granted medRxiv a license to display the preprint in perpetuity. All rights reserved. No reuse allowed without permission.

250

251

252

253

254

255

256

257

258

259

260

In this region, São Paulo state shows the highest number of cases $(58,378)$ with 4,501 deaths until 15 May 2020. In the city of São Paulo alone, 33,992 cases were confirmed with 2,674 deaths, making it the most affected municipality in the Southeast, followed by Rio de Janeiro, with 11.715 cases and 1,631 deaths on 15 May. In MG, the city with the highest number of cases and deaths, Belo Horizonte, had 1,088 confirmed cases and 29 deaths, while in ES the largest number of cases occurred in Vila Velha, a city very close to the capital (Vitória), with 1,305 and 43 deaths. Complete data on population, health determinants and indicators, as well as on notification of COVID-19 cases in the Southeast region, from the beginning of pandemic until 15 May 2020, are shown in Table 2.

The South region comprises the states of Paraná (PR), Santa Catarina (SC) and Rio Grande do Sul (RS). The first confirmed patient with COVID-19 in the region was in the city of Campo Bom, RS. In this region, the state of SC stands out with the highest incidence in the South on 14 April and the highest increase until 15 May. Information about population, health determinants and indicators and about notification of COVID-19 cases in the South region, from the first registered case until 15 May 2020, are shown in Table 3.

Finally, the Midwest region is composed of the states of Mato Grosso (MT), Mato Grosso do Sul (MS), Goiás (GO) and the Federal District (DF). The first confirmed case in the region occurred on 7 March 2020, in DF. On 15 May 2020, DF had 3,787 confirmed cases and 55 deaths. Complete data for this region is also showed in Table 3 and Fig 1 and 2. 
medRxiv preprint doi: https://doi.org/10.1101/2020.06.02.20120220; this version posted June 5, 2020. The copyright holder for this preprint (which was not certified by peer review) is the author/funder, who has granted medRxiv a license to display the preprint in perpetuity.

All rights reserved. No reuse allowed without permission. 
Table 2. Notification of COVID-19 in the Southeast region of Brazil until 15 May 2020

\begin{tabular}{|c|c|c|c|c|c|}
\hline SOUTHEAST & MG & ES & $\mathbf{R J}$ & SP & Total \\
\hline Population ${ }^{1}$ & $\begin{array}{c}21,168,791 \\
23.95 \%\end{array}$ & $\begin{array}{c}4,018,650 \\
4.55 \%\end{array}$ & $\begin{array}{c}17,264,943 \\
19.54 \%\end{array}$ & $\begin{array}{c}45,919,049 \\
51.96 \%\end{array}$ & $\begin{array}{r}88,371,433 \\
100 \%\end{array}$ \\
\hline Elderly $(\geq 65 y)^{1}$ & $2,288,973$ & 382,976 & $1,998,280$ & $4,792,036$ & $9,462,265$ \\
\hline Total number of cities & 853 & 78 & 92 & 645 & 1,668 \\
\hline Per capita income $(\mathrm{R} \$)$ & 749.69 & 815.43 & 1039.3 & 1084.46 & \\
\hline Inadequate water supply and sewerage (\%) & 1.84 & 0.99 & 1.67 & 0.6 & \\
\hline SVI & 0.282 & 0.274 & 0.323 & 0.297 & \\
\hline HDI & 0.731 & 0.740 & 0.761 & 0.783 & \\
\hline Hospital beds in SUS & 26,896 & 5,100 & 21,108 & 52,302 & 105,406 \\
\hline ICU beds in SUS & 3,478 & 641 & 2,612 & 7,331 & 14,062 \\
\hline Total hospital beds & 40,675 & 7,929 & 32,736 & 90,146 & 171,486 \\
\hline Population/hospital beds & 520 & 507 & 527 & 509 & 515 \\
\hline Date of $1^{\text {st }}$ case & 08.03 .20 & 06.03 .20 & 05.03 .20 & 26.02 .20 & 26.02.20 \\
\hline Total cases, March & 275 & 84 & 708 & 2339 & 3,406 \\
\hline Deaths, March & 2 & 0 & 23 & 136 & 161 \\
\hline Social isolation (\%) in 14 April 2020 & 43.35 & 44.49 & 48.59 & 46.8 & \\
\hline Cases until 14 April 2020 & 870 & 463 & 3,220 & 9,263 & 4,553 \\
\hline Death until 14 April 2020 & 25 & 17 & 182 & 695 & 224 \\
\hline Incidence on 14 April 2020* & 4.11 & 11.52 & 18.65 & 20.17 & 5.15 \\
\hline Social isolation (\%) in 30 April 2020 & 51.0 & 51.3 & 54.4 & 51.4 & \\
\hline Cases until 30 April 2020 & 1,827 & 2,465 & 9,453 & 28,698 & 42,443 \\
\hline Death until 30 April 2020 & 82 & 83 & 854 & 2,375 & 3,394 \\
\hline Incidence on 30 April $2020^{*}$ & 8.63 & 61.34 & 54.75 & 62.5 & 48.03 \\
\hline Cases until 15 May 2020 & 4,196 & 6,198 & 19,987 & 58,378 & 88,759 \\
\hline Death until 15 May 2020 & 146 & 260 & 2,438 & 4,501 & 7,345 \\
\hline Incidence on 15 May 2020 & 19.82 & 154,23 & 115,77 & 127.13 & 100.44 \\
\hline
\end{tabular}

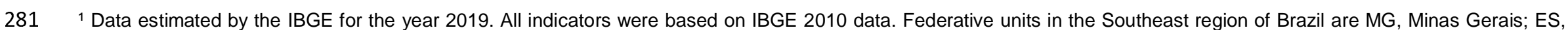

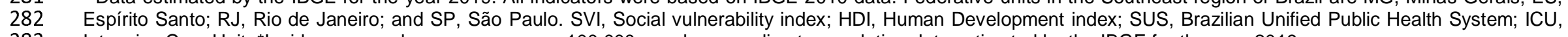


Table 3. Notification of COVID-19 in the South and Midwest regions of Brazil until 15 May 2020

\begin{tabular}{|c|c|c|c|c|}
\hline SOUTH & PR & SC & RS & Total \\
\hline Population ${ }^{1}$ & $\begin{array}{c}11,433,957 \\
38.14 \%\end{array}$ & $\begin{array}{c}7,164,788 \\
23.90 \%\end{array}$ & $\begin{array}{c}11,377,2 \% 39 \\
37.95 \%\end{array}$ & $\begin{array}{r}29,975,984 \\
100 \%\end{array}$ \\
\hline Elderly $(\geq 65 y)^{1}$ & $1,175,396$ & 703,354 & $1,441,194$ & $3,319,944$ \\
\hline Total number of cities & 399 & 295 & 497 & 1,191 \\
\hline Per capita income $(\mathrm{R} \$)$ & 890.89 & 983.9 & 959.24 & \\
\hline Inadequate water supply and sewerage (\%) & 0.97 & 0.78 & 0.89 & \\
\hline SVI & 0.252 & 0.192 & 0.234 & \\
\hline HDI & 0.749 & 0.774 & 0.746 & \\
\hline Hospital Beds in SUS & 18,494 & 10,921 & 20,366 & 49,781 \\
\hline ICU beds in SUS & 2,303 & 1,027 & 2,188 & 5,518 \\
\hline Total hospital beds & 27,502 & 15,322 & 30,123 & 72,947 \\
\hline Population/hospital beds & 416 & 468 & 378 & 411 \\
\hline Date of $1^{\text {st }}$ case & 12.03 .20 & 13.03 .20 & 10.03 .20 & 10.03.20 \\
\hline Total cases, March & 179 & 219 & 274 & 672 \\
\hline Deaths, March & 3 & 2 & 4 & 9 \\
\hline Social isolation (\%) in 14 April 2020 & 42.64 & 41.93 & 45.37 & \\
\hline Cases until 14 April 2020 & 755 & 814 & 685 & 2,254 \\
\hline Deaths until 14 April 2020 & 32 & 26 & 17 & 75 \\
\hline Incidence on 14 April $2020^{*}$ & 6.60 & 11.36 & 6.02 & 7.52 \\
\hline Social isolation (\%) in 30 April 2020 & 48.4 & 47.2 & 50.5 & \\
\hline Cases until 30 April 2020 & 1,407 & 2,085 & 1,466 & 4,958 \\
\hline Deaths until 30 April 2020 & 83 & 46 & 51 & 180 \\
\hline Incidence on 30 April 2020* & 12.31 & 29.1 & 12.89 & 16.54 \\
\hline Cases until 15 May 2020 & 2,139 & 4,597 & 3,597 & 10,333 \\
\hline Deaths until 15 May 2020 & 120 & 79 & 126 & 325 \\
\hline Incidence on 15 May 2020 & 18.71 & 64.16 & 31.62 & 34.47 \\
\hline MIDWEST & MS & MT & GO & Total \\
\hline Population 1 & $\begin{array}{c}2,778,986 \\
17.05 \%\end{array}$ & $\begin{array}{c}3,484,466 \\
21.38 \%\end{array}$ & $\begin{array}{c}7,018,354 \\
43.07 \%\end{array}$ & $\begin{array}{r}16,297,074 \\
100 \%\end{array}$ \\
\hline
\end{tabular}




\begin{tabular}{|c|c|c|c|c|c|}
\hline Elderly $(\geq 65 y)^{1}$ & 238,889 & 243,822 & 560,233 & 217,292 & $1,260,236$ \\
\hline Total number of cities & 79 & 141 & 246 & 1 & 467 \\
\hline Per capita income $(\mathrm{R} \$)$ & 799.34 & 762.52 & 810.97 & 1715.11 & \\
\hline Inadequate water supply and sewerage (\%) & 3.93 & 5.16 & 3.38 & 0.72 & \\
\hline SVI & 0.289 & 0.277 & 0.331 & 0.294 & \\
\hline HDI & 0.729 & 0.725 & 0.735 & 0.824 & \\
\hline Hospital Beds in SUS & 3,667 & 5,113 & 10,552 & 3,959 & 23,291 \\
\hline ICU beds in SUS & 403 & 487 & 969 & 383 & 2,242 \\
\hline Total hospital beds & 5,586 & 7,156 & 17,445 & 6,705 & 36,892 \\
\hline Population/hospital beds & 497 & 487 & 402 & 450 & 442 \\
\hline Date of $1^{\text {st }}$ case & 16.03 .20 & 20.03 .20 & 13.03 .20 & 07.03 .20 & 07.03 .20 \\
\hline Total cases, March & 48 & 25 & 65 & 332 & 470 \\
\hline Deaths, March & 1 & 0 & 1 & 3 & 5 \\
\hline Social isolation (\%) in 14 April 2020 & 36.69 & 37.8 & 50.22 & 55.9 & \\
\hline Cases until 14 April 2020 & 113 & 131 & 233 & 641 & 1,118 \\
\hline Deaths until 14 April 2020ril 14, 2020 & 4 & 4 & 15 & 15 & 38 \\
\hline Incidence on 14 April 2020* & 4.07 & 3.76 & 3.32 & 21.26 & 6.86 \\
\hline Social isolation (\%) in 30 April 2020 & 44.0 & 47.7 & 61.0 & 61.0 & \\
\hline Cases until 30 April 2020 & 255 & 297 & 781 & 1,356 & 2,689 \\
\hline Deaths until 30 April 2020 & 9 & 11 & 29 & 30 & 79 \\
\hline Incidence on 30 April 2020* & 9.18 & 8.52 & 11.13 & 44.97 & 16.50 \\
\hline Cases until 15 May 2020 & 479 & 779 & 1,572 & 3,787 & 6,617 \\
\hline Deaths until 15 May 2020 & 14 & 26 & 67 & 55 & 162 \\
\hline Incidence on 15 May 2020 & 17.24 & 22.36 & 22.40 & 125.59 & 40.60 \\
\hline
\end{tabular}

2861 Data estimated by the IBGE for the year 2019. All indicators were based on IBGE 2010 data. Federative units in the South region of Brazil are PR, Paraná; SC, Santa

287 Catarina; and RS, Rio Grande do Sul; and in the Midwest region of Brazil are MS, Mato Grosso do Sul; MT, Mato Grosso; GO, Goiás; and DF, Distrito Federal. SVI, Social

288 vulnerability index; HDI, Human Development index; SUS, Brazilian Unified Public Health System; ICU, Intensive Care Unit. *Incidence was shown as cases per 100,000,

289 according to population data estimated by the IBGE for the year 2019. 
medRxiv preprint doi: https://doi.org/10.1101/2020.06.02.20120220; this version posted June 5, 2020. The copyright holder for this preprint (which was not certified by peer review) is the author/funder, who has granted medRxiv a license to display the preprint in perpetuity.

All rights reserved. No reuse allowed without permission.

Incidence rates and case fatality rates (\%) in three time points (14 and 30 April, and 15 May), ranked in decreasing order, as well as SVI scores and inadequate water supply and sewerage rates (\%), by federative unit, are demonstrated in Fig 1. Regarding incidence rates (cases per 100,000), the top five federative units in 14 April 2020, in decreasing order, were AM and AP (North), DF (Midwest), CE (Northeast) and SP (Southeast), all with more than 20 cases per 100,000, Fig 1A. In 30 April 2020, the states with highest incidence rates were AP, $\mathrm{AM}$ and RR (North), CE and PE (Northeast), all with incidence rates above 70 cases per 100,000 . As for fatality rates, considering all 27 states in the country, RJ and SP had the highest scores, followed by PE, AM and PB. It is important to highlight that, despite PB is just the $17^{\text {th }}$ of 27 states in terms of incidence, it appears as the fifth when lethality is measured (Fig 1C). In the last evaluation, the top of five federative units in 15 May 2020, in decreasing order, were AM (incidence: 443.76), AP (429.21) and RR (262.31) (North), CE with incidence 246.27 (Northeast) and AC (246.27) (North). Fourteen states had incidences greater than 150 per 100.00 on that date Fig $1 \mathrm{E}$.

The increase in cases over the course of a month, based on the ratio between incidences per 100,000 on 15 May and 14 April 2020, is shown in Fig 2A. Considering the increasing in incidence rates of COVID-19 cases during this period, the states with the highest levels, in decreasing order, were SE, AL, TO, PA and PI.

When federative units were stratified into two groups according to the rate of inadequate water supply and sewerage $(<9 \%$ or $\geq 9 \%)$, those with rates $>9 \%$ were 5.63 times more likely to have an incidence greater than 30 cases/100,000 ( $P=0.041)$, as shown in Fig 2B.

Stratifying increases in cases over this one-month period into quartiles revealed how SVI and HDI scores were strongly associated with higher values of incidence ratio in North and Northeast states (Fig 2C and D).

The SVI data for the 27 federative units were moderately and directly correlated with the incidence of cases on 15 May $\left(r h_{0}=0.575\right.$ and $\left.P=0.002\right)$. There was a strong and direct 
medRxiv preprint doi: https://doi.org/10.1101/2020.06.02.20120220; this version posted June 5, 2020. The copyright holder for this preprint (which was not certified by peer review) is the author/funder, who has granted medRxiv a license to display the preprint in perpetuity.

All rights reserved. No reuse allowed without permission.

correlation between increases in the incidence rate during the one-month period covered in the study and SVI scores $\left(\mathrm{rh}_{0}=0.727\right.$ and $\left.\mathrm{P}<0.001\right)$

Finally, updated data on numbers of cases, incidence rates, number of deaths, and case-fatality, until 22 May 2020 is presented in Fig 3. Data about incidence rate of COVID-19 on 22 May 2020 could be found in S1 Fig.

Figure 3. Distribution of cases and incidence rates (A), deaths and case-fatality (B) in the 27 federative units of Brazil on 22 May 2020 [16]. * Incidence rates were calculated according to Brazilian Institute of Geography and Statistics estimative to Brazilian population in the year 2019 [17].

\section{Discussion}

Brazil is the fifth largest country in the world, with an area of $8,514,876$ square kilometres divided into 27 federative units (26 states and 1 federal district), and a total of 5,570 cities [17]. Partly because of its large dimension, Brazil is a very heterogeneous country, with wide regional differences related to climate, lifestyle habits, socioeconomic characteristics, human development, social vulnerability, rates of inadequate water supply and sewage, population density across the states, and education level of the population [25]. Therefore, a single curve in the number of cases over time would not be representative of the whole country, due to a slower spread to the interior in some federative units. Thus, our main results are presented according to the five regions that comprise it.

Despite being the last of the five Brazilian regions to register a first case of COVID19, the North region was one of the first to have a city with a health system overload. Currently, this is the case of Manaus, the capital of AM, where the mayor acknowledged a "collapse in the health system" and many patients are not getting access to proper health care, several of them dying at home [26]. This situation is even worse because Manaus is the only city in AM (the biggest state in the country) that has beds in intensive care units and, therefore, concentrates all intensive care in the state. This state also has few roads, and transport is mainly by rivers. The high incidences of COVID-19 in AM and AP, seen on 15 
medRxiv preprint doi: https://doi.org/10.1101/2020.06.02.20120220; this version posted June 5, 2020. The copyright holder for this preprint (which was not certified by peer review) is the author/funder, who has granted medRxiv a license to display the preprint in perpetuity.

All rights reserved. No reuse allowed without permission.

346 May, place these two states at the top of national ranking, as compared to states with the

347 highest incidence rates in other regions. In addition, four of the seven states in the North, 348 including $\mathrm{AM}$ and $\mathrm{AP}$, present high SVI scores, and the worst rate of hospital beds per 349 population over the country is found precisely in these two states, which would partly explain

350

The fight against COVID-19 becomes even more worrying because AM has a population of approximately 168,000 indigenous natives, representing $20 \%$ of the total indigenous population in Brazil. These populations are known to be more susceptive to epidemics and vulnerable to the occurrence of health conditions in general due to unfavourable socioeconomic conditions [27]. Furthermore, indigenous communities usually live in isolated areas, far from medical posts, doctors, and access to basic medicines [26].

Northeast is the second most populous region in the country. Although social isolation rates in the Northeast states on 15 May were among the highest of the entire country, the region also has the second highest number of cases and deaths by COVID-19. Two states in this region, $C E$ and $P E$, had incidence increases and lethality rates due to COVID-19 in 15 May higher than SP, the state from Southeast region with the highest numbers cases and deaths due to this disease. It is important to note that both CE and PE have higher SVI scores and inadequate water supply and sewerage rates than SP, which may explain, at least in part, those differences. These observations suggest that socioeconomic context and social inequality play a role in the spread of COVID-19 in Brazil, as observed in the North. Supporting this hypothesis, states in the North and Northeast with higher SVI scores showed greater increases in the incidence rate from 14 April to 15 May. Khalatbari-Soltani et al. (2020) highlight the role that socioeconomic characteristics may play in transmission, incidence and health outcomes in COVID-19, as well as the need for high-quality data on socioeconomic factors, which can be useful in the development and implementation of public health actions [28]. 
medRxiv preprint doi: https://doi.org/10.1101/2020.06.02.20120220; this version posted June 5, 2020. The copyright holder for this preprint (which was not certified by peer review) is the author/funder, who has granted medRxiv a license to display the preprint in perpetuity.

All rights reserved. No reuse allowed without permission.

The Southeast region includes the three largest metropolitan areas in Brazil, that is,

375 the cities of São Paulo, Rio de Janeiro and Belo Horizonte; and the main industrialized

376 areas. It is also the region with the biggest population among the five Brazilian political

377 regions, as well as the one with the highest numbers of cases and deaths by COVID-19. The

first case reported in Brazil, in São Paulo city, occurred on a date very close to the Carnival party (21 to 26 February 2020). The arrival and the beginning of the spread of COVID-19 in the Brazilian capitals may have occurred at the time of this party.

Brazilian carnival is well known all over the world and attracts many foreigners to the main cities of the country. In this traditional Brazilian party, most of the population takes to the streets in immense agglomerations, to the sound of typical local rhythms, mainly samba. Although Carnival took place before the first reported case of COVID-19 in Brazil, many people may have been infected at that time and some of them may have had asymptomatic illness or mild flu, which was not reported.

South region has the lowest numbers of cases and deaths, as well as the lowest incidence rates of COVID-19, along with the Midwest region, which may be reflect the fact that both regions have the smallest populations among the five Brazilian political regions. At least in the South, this may be explained, in part, by the rate of inadequate water supply and sewerage, less than $1 \%$ in all three states, and by the low scores on SVI. There are concerns about the effects of winter, which is more pronounced in this region and whose coldest months are just ahead (May to August). While data on SARS-CoV-2 seasonality is not yet clear, routine diagnostics records show a strong and consistent seasonal variation of the four previous coronavirus epidemics (229E, HKU1, NL63, OC43) [29]. In this line, a study based on data from 130 Chinese cities, between 20 January and 2 March 2020, pointed out that lower temperature and humidity are likely to favour the transmission of COVID-19 [30]. Thus, concerns about increased spread during the winter months seem to make a lot of sense. On the other hand, a recent study evaluating meteorological factors related to the spread of

400 COVID-19, conducted in five cities of Brazil, showed it is favoured by higher mean 401 temperatures $\left(27.5^{\circ} \mathrm{C}\right)$ as well as intermediate relative humidity (in the range of $80 \%$ ), 
medRxiv preprint doi: https://doi.org/10.1101/2020.06.02.20120220; this version posted June 5, 2020. The copyright holder for this preprint (which was not certified by peer review) is the author/funder, who has granted medRxiv a license to display the preprint in perpetuity.

All rights reserved. No reuse allowed without permission.

402 although the study was carried out entirely before winter in Brazil [31]. Although these 403 meteorological conditions are compatible with those observed in Manaus, AM, in the North, 404 in this study we demonstrated that other factors, such as health indicators, are more important to explain the greater numbers of cases and deaths in this region.

Two states in the Midwest, MT and MS, had reported less than 800 cases of COVID-

40719 on 15 May 2020, while GO had 1,572 cases on the same date. These three states had 408 low incidence rates, ranging 17.24 to 22.40 per 100,000 individuals. DF is an exception in Midwest region, with the highest number of cases $(3,787)$ and incidence rate $(125.59$ per $100,000)$. The lower numbers of cases in MT and MS may be related to the presence of a large rural area and to the closure of borders between federative units, since these states presented the lowest social isolation rates in the county (less than 40\%). On the other hand, as it contains the Brazilian capital (Brasília), DF has a greater circulation of people compared to the rest of the Midwest region, with a greater number of both national and international flights, which may explain part of this higher incidence within Midwest.

We believe that, in Brazil, cases of COVID-19 may be underreported, since the number of diagnostic tests available is much lower than necessary. In addition, testing for COVID-19 has been reduced only to people admitted to hospitals, and yet it is not enough for everyone. Many Brazilians died in their homes, which may cause fatal cases of COVID-19 to be underreported in our country. No widespread testing on all suspected cases has been performed. In a population-based study conducted in the state of RS, in April 2020, reported cases represented only around $10 \%$ of all detected cases [32]. In addition, states registries 423 show higher numbers of deaths than Ministry of Health reports, which may indicate that 424 fatality cases are underestimated. According to this data, since the epidemic beginning in Brazil, registries reported 58,839 deaths caused by SARS, respiratory failure and pneumonia, and only 12,344 deaths by COVID-19. In this regard, other studies have highlighted the potential for undocumented cases and low estimation due to limited testing in

428 China to the spread of SARS-CoV-2 [33], and also in Brazil whose numbers of cases and 429 deaths can be much higher than the official data released [34]. 
medRxiv preprint doi: https://doi.org/10.1101/2020.06.02.20120220; this version posted June 5, 2020. The copyright holder for this preprint (which was not certified by peer review) is the author/funder, who has granted medRxiv a license to display the preprint in perpetuity.

All rights reserved. No reuse allowed without permission.

430 The main results of our study are in line with other previously published reports, 431 showing that disadvantaged socioeconomic regions and poor health indicators perform 432 worse during sanitary crises, with higher risks of disease and mortality [28, 35]. There is no 433 reason to believe that the COVID-19 pandemic is an exception; as we showed here, regions 434 of poor health determinants performed worse against the disease.

435 In low-income populations, where absolute poverty is a major problem, access to 436 basic needs, such as clean water, sanitation and food, will have a substantial impact on how 437 easily people can practice any social distancing measures. Furthermore, in low- and middle438 income regions, people are more likely to live in overcrowded homes or neighbourhoods, making it impossible to isolate elderly or vulnerable people [28].

$440 \quad$ Before COVID-19 pandemic, Brazil was already facing an economic crisis, with 11.6 441 million unemployed in the fourth quarter of 2019 [36]. As of March 2020, during the 442 outbreak of the SARS-CoV-2, there were more than 38 million informally self-employed 443 people in Brazil, with no Social Security coverage or any other forms of protection [37]. 444 Although emergency financial support has been settled by Federal Government for informal 445 workers, the amount granted is less than 60\% (about \$ 110 US dollars) of the minimal 446 income established in the country. This circumstance may have reduced the rate of social 447 isolation, especially among the lower middle- and low-income people. A delay in the 448 implementation of social policies leads to an aggravation of this health crisis and we believe 449 it may also have influenced people to a lower adhesion to social isolation and, consequently, 450 to the increase in the spread of COVID-19.

451 Furthermore, the Brazilian Federal Government took a stand against WHO 452 recommendations regarding social isolation during COVID-19 pandemic, with several 453 speeches neglecting the severity of the disease and the need for social isolation, in favour of 454 the country's economic development. We believe that these speeches may also have 455 influenced people to a lower adhesion to social isolation and, consequently, to the increase 456 in cases and deaths due to COVID-19. 
medRxiv preprint doi: https://doi.org/10.1101/2020.06.02.20120220; this version posted June 5, 2020. The copyright holder for this preprint (which was not certified by peer review) is the author/funder, who has granted medRxiv a license to display the preprint in perpetuity. All rights reserved. No reuse allowed without permission.

When the history of COVID-19 is told, Brazil will likely be remembered as the country 458 with the highest number of cases in Latin America (330,890 cases with 21,048 deaths as of 45922 May) [16]. Unfortunately, this sad historical data will describe countless deaths and a 460 drastic increase in unemployment and hunger, as well as each measure taken by the 461 governments of the countries affected by COVID-19. During this pandemic, people in Brazil 462 find themselves divided between two different guidelines on what they should do: on the one 463 hand, a strong campaign by the media, the minister of Health, governors and mayors, urging 464 people to maintain social isolation and stay home. On the other hand, the attitudes of the 465 President of Brazil, sowing confusion, openly disrespecting and discouraging sensible measures of physical distancing and lockdown, and stimulating frequent political crises during this period, as very well described and documented in a recent editorial published in The Lancet [38].

The limitations of this study include those related to incomplete information from government databases, which depend on inputs from thousands of different cities about cases and deaths, and the data of Brazilian last census, carried out in 2010. In addition,

472 there is a restriction of tests for SARS-CoV-2 in the Brazilian population, which produces 473 underestimated information.

474 Data presented in 15 May 2020 demonstrate that Brazil is still far from reaching the 475 epidemic peak and suggest that actions to support the disadvantaged population by the 476 government should be improved, since a large number of Brazilians live in poverty, in small 477 houses with a great number of people, who share the same rooms, where social isolation is 478 unfeasible. Despite this, in line with WHO recommendations, we believe that social isolation 479 should be encouraged by the government and employers as far as possible, in order to 480 prevent the spread of COVID-19 and further increases in cases and deaths.

481

\section{Acknowledgements}


medRxiv preprint doi: https://doi.org/10.1101/2020.06.02.20120220; this version posted June 5, 2020. The copyright holder for this preprint (which was not certified by peer review) is the author/funder, who has granted medRxiv a license to display the preprint in perpetuity.

All rights reserved. No reuse allowed without permission.

483 EMG-S thanks the Universidade Federal Mato Grosso do Sul (UFMS) for the opportunity of 484 being a visiting professor (contract PROGEP/RTR No 2019/000230). This study was partly 485 financed by the Coordination for the Improvement of Higher Education Personnel - Brazil 486 (Coordenação de Aperfeiçoamento de Pessoal de Nível Superior (CAPES)), through the 487 granting of scholarships to postgraduate students. We thank the Federal University of Mato 488 Grosso do Sul (UFMS) for the support for language revision and payment of publication 489 charge by EDITAL PROPP / UFMS № 143/2019.

491 Authors' contributions

492 EMG-S designed the research study, analysed the data, performed statistical analysis, and 493 wrote the paper. CP, GWG, SSW, EJS and TBRG collaborated in the writing of the 494 manuscript. Acquisition of data and references, EJS, ICP, KGJ, RFAZ, and AGB. Analysis 495 and interpretation of data were also performed by EMG-S, SSW, EJS, CP, and GWG. Critical 496 revision, EMG-S, CP, GWG, TBRG, SSW, and ADC.

498 Disclosure statement

499 The authors have no conflicts of interest to declare. 
medRxiv preprint doi: https://doi.org/10.1101/2020.06.02.20120220; this version posted June 5, 2020. The copyright holder for this preprint (which was not certified by peer review) is the author/funder, who has granted medRxiv a license to display the preprint in perpetuity.

\section{References}

1. Zhu N, Zhang D, Wang W, Li X, Yang B, Song J, et al. A Novel Coronavirus from Patients with Pneumonia in China, 2019. N Engl J Med. 2020;382(8):727-33. Epub 2020/01/24. doi: 10.1056/NEJMoa2001017. PubMed PMID: 31978945; PubMed Central PMCID: PMCPMC7092803.

2. Li Q, Guan X, Wu P, Wang X, Zhou L, Tong Y, et al. Early Transmission Dynamics in Wuhan, China, of Novel Coronavirus-Infected Pneumonia. N Engl J Med.

2020;382(13):1199-207. Epub 2020/01/29. doi: 10.1056/NEJMoa2001316. PubMed PMID: 31995857; PubMed Central PMCID: PMCPMC7121484.

3. Chen N, Zhou M, Dong X, Qu J, Gong F, Han Y, et al. Epidemiological and clinical characteristics of 99 cases of 2019 novel coronavirus pneumonia in Wuhan, China: a descriptive study. Lancet. 2020;395(10223):507-13. Epub 2020/01/30. doi: 10.1016/S01406736(20)30211-7. PubMed PMID: 32007143; PubMed Central PMCID: PMCPMC7135076. 4. WHO. Coronavirus disease 2019 (COVID-19). Situation Report - 59. Geneva: World Health Organization; 2020.

5. Cucinotta D, Vanelli M. WHO Declares COVID-19 a Pandemic. Acta Biomed. 2020;91(1):157-60. Epub 2020/03/19. doi: 10.23750/abm.v91i1.9397. PubMed PMID: 32191675.

6. Lippi G, Sanchis-Gomar F, Henry BM. Coronavirus disease 2019 (COVID-19): the portrait of a perfect storm. Ann Transl Med. 2020;8(7):7.

7. Rothe C, Schunk M, Sothmann P, Bretzel G, Froeschl G, Wallrauch C, et al. Transmission of 2019-nCoV Infection from an Asymptomatic Contact in Germany. N Engl J Med. 2020;382(10):970-1. Epub 2020/01/30. doi: 10.1056/NEJMc2001468. PubMed PMID: 32003551; PubMed Central PMCID: PMCPMC7120970.

8. Phan LT, Nguyen TV, Luong QC, Nguyen HT, Le HQ, Nguyen TT, et al. Importation and Human-to-Human Transmission of a Novel Coronavirus in Vietnam. N Engl J Med. 2020;382(9):872-4. Epub 2020/01/28. doi: 10.1056/NEJMc2001272. PubMed PMID: 31991079 ; PubMed Central PMCID: PMCPMC7121428.

9. Wu Z, McGoogan JM. Characteristics of and Important Lessons From the Coronavirus Disease 2019 (COVID-19) Outbreak in China: Summary of a Report of $72 \square 314$ Cases From the Chinese Center for Disease Control and Prevention. JAMA. 2020. Epub 2020/02/24. doi: 10.1001/jama.2020.2648. PubMed PMID: 32091533.

10. Guan WJ, Ni ZY, Hu Y, Liang WH, Ou CQ, He JX, et al. Clinical Characteristics of Coronavirus Disease 2019 in China. N Engl J Med. 2020. Epub 2020/02/28. doi: 10.1056/NEJMoa2002032. PubMed PMID: 32109013; PubMed Central PMCID: PMCPMC7092819.

11. Bai Y, Yao L, Wei T, Tian F, Jin DY, Chen L, et al. Presumed Asymptomatic Carrier Transmission of COVID-19. JAMA. 2020. Epub 2020/02/21. doi: 10.1001/jama.2020.2565. PubMed PMID: 32083643; PubMed Central PMCID: PMCPMC7042844.

12. Zhang L, Shen FM, Chen F, Lin Z. Origin and evolution of the 2019 novel coronavirus. Clin Infect Dis. 2020. Epub 2020/02/03. doi: 10.1093/cid/ciaa112. PubMed PMID: 32011673; PubMed Central PMCID: PMCPMC7108176. 
medRxiv preprint doi: https://doi.org/10.1101/2020.06.02.20120220; this version posted June 5, 2020. The copyright holder for this preprint (which was not certified by peer review) is the author/funder, who has granted medRxiv a license to display the preprint in perpetuity.

All rights reserved. No reuse allowed without permission.

572 13. Shen Z, Xiao Y, Kang L, Ma W, Shi L, Zhang L, et al. Genomic diversity of SARS-

573 CoV-2 in Coronavirus Disease 2019 patients. Clin Infect Dis. 2020. Epub 2020/03/04. doi:

574

575

576

577

578

579

580

581

582

583

584

585

586

587

588

589

590

591

592

593

594

595

596

597

598

599

600

601

602

603

604

605

606

607

608

609

610

611

612

613

614

615

616

617

618

619

620

621

622

623

624

10.1093/cid/ciaa203. PubMed PMID: 32129843; PubMed Central PMCID:

PMCPMC7108196.

14. Yu P, Zhu J, Zhang Z, Han Y, Huang L. A familial cluster of infection associated with the 2019 novel coronavirus indicating potential person-to-person transmission during the incubation period. J Infect Dis. 2020. Epub 2020/02/18. doi: 10.1093/infdis/jiaa077. PubMed PMID: 32067043; PubMed Central PMCID: PMCPMC7107453.

15. WHO. Coronavirus disease (COVID-19).Situation Report - 123. Geneva: World Health Organization; 2020.

16. BRASIL. Painel Coronavírus. Brasília: Ministério da Saúde; 2020.

17. IBGE. Population estimates with reference to July 1, 2019. Rio de Janeiro: Brazilian Institute of Geography and Statistics 2019.

18. IBGE. Brazil Demographic Census 2010. Rio de Janeiro: Brazilian Institute of Geography and Statistics; 2010.

19. BRASIL. Departamento de Informática do Sistema Único de saúde (DATASUS). Brasília: Ministério da Saúde; 2020.

20. Mapa brasileiro da COVID-19 [Internet]. Inloco. 2020 [cited 14 April 2020]. Available from: <https://www.inloco.com.br/pt/covid-19?hsCtaTracking=5a87f305-e68e-49be-b04cf3afec6d948c\%7C91d9a390-f6a7-4e9e-abc0-b26f84f1d519>.

21. Human Development Atlas Brasil [Internet]. United Nations Development Programme (UNDP), Institute of Applied Economic Research (IPEA), João Pinheiro Foundation (FJP). 2013 [cited 14 April 2020]. Available from: <http://www.atlasbrasil.org.br/2013/en/>.

22. Costa MA, Marguti BO. Atlas de vulnerabilidade social dos municípios brasileiros. In: República SdAEdPd, editor. Brasília: IPEA; 2015.

23. Plataforma de Informações Espaciais da COVID-19 (PIE-COVID). Instituto Federal de Educação, Ciência e Tecnologia do Rio Grande do Sul. 2020.

24. BRASIL. Resolução n 510, de 07 de abril de 2016. Brasília: Conselho Nacional de Saúde; 2016.

25. Paim J, Travassos C, Almeida C, Bahia L, Macinko J. The Brazilian health system: history, advances, and challenges. Lancet. 2011;377(9779):1778-97. Epub 2011/05/09. doi: 10.1016/S0140-6736(11)60054-8. PubMed PMID: 21561655.

26. Ferrante L, Fearnside PM. Protect Indigenous peoples from COVID-19. Science. 2020;368(6488):251. doi: 10.1126/science.abc0073. PubMed PMID: 32299940.

27. Castro DB, Pinto RC, Albuquerque BC, Sadahiro M, Braga JU. The Socioeconomic Factors and the Indigenous Component of Tuberculosis in Amazonas. PLoS One.

2016;11(6):e0158574. Epub 2016/06/30. doi: 10.1371/journal.pone.0158574. PubMed PMID: 27362428; PubMed Central PMCID: PMCPMC4928831.

28. Khalatbari-Soltani S, Cumming RG, Delpierre C, Kelly-Irving M. Importance of collecting data on socioeconomic determinants from the early stage of the COVID-19 outbreak onwards. J Epidemiol Community Health. 2020. Epub 2020/05/08. doi: 10.1136/jech-2020-214297. PubMed PMID: 32385126.

29. Neher RA, Dyrdak R, Druelle V, Hodcroft EB, Albert J. Potential impact of seasonal forcing on a SARS-CoV-2 pandemic. Swiss Med Wkly. 2020;150:w20224. Epub 2020/03/16. doi: 10.4414/smw.2020.20224. PubMed PMID: 32176808.

30. Liu J, Zhou J, Yao J, Zhang X, Li L, Xu X, et al. Impact of meteorological factors on the COVID-19 transmission: A multi-city study in China. Sci Total Environ. 2020;726:138513. Epub 2020/04/09. doi: 10.1016/j.scitotenv.2020.138513. PubMed PMID: 32304942; PubMed Central PMCID: PMCPMC7194892.

31. Auler AC, Cássaro FAM, da Silva VO, Pires LF. Evidence that high temperatures and intermediate relative humidity might favor the spread of COVID-19 in tropical climate: A case study for the most affected Brazilian cities. Sci Total Environ. 2020;729:139090. Epub 2020/04/28. doi: 10.1016/j.scitotenv.2020.139090. PubMed PMID: 32388137. 
medRxiv preprint doi: https://doi.org/10.1101/2020.06.02.20120220; this version posted June 5, 2020. The copyright holder for this preprint (which was not certified by peer review) is the author/funder, who has granted medRxiv a license to display the preprint in perpetuity. All rights reserved. No reuse allowed without permission.

625 32. EPICOVID19. Epidemiologia da COVID-19 no Rio Grande do Sul. Estudo de base 626 populacional. In: Secretaria de Planejamento, Orçamento e Gestão do Estado do Rio 627 Grande do Sul. Porto Alegre: Governo do Estado do Rio Grande do Sul; 2020.

628 33. Li R, Pei S, Chen B, Song Y, Zhang T, Yang W, et al. Substantial undocumented 629 infection facilitates the rapid dissemination of novel coronavirus (SARS-CoV-2). Science. 630 2020;368(6490):489-93. Epub 2020/03/16. doi: 10.1126/science.abb3221. PubMed PMID: 631 32179701; PubMed Central PMCID: PMCPMC7164387.

632 34. Requia WJ, Kondo EK, Adams MD, Gold DR, Struchiner CJ. Risk of the Brazilian 633 health care system over 5572 municipalities to exceed health care capacity due to the 2019 634 novel coronavirus (COVID-19). Sci Total Environ. 2020;730:139144. Epub 2020/05/01. doi: 635 10.1016/j.scitotenv.2020.139144. PubMed PMID: 32380368.

636 35. Solis J, Franco-Paredes C, Henao-Martínez AF, Krsak M, Zimmer SM. Structural 637 Vulnerability in the United States Revealed in Three Waves of Novel Coronavirus Disease 638 (COVID-19). Am J Trop Med Hyg. 2020. Epub 2020/05/07. doi: 10.4269/ajtmh.20-0391. 639 PubMed PMID: 32383432.

640 36. IBGE. Desemprego. Rio de Janeiro: Brazilian Institute of Geography and Statistics; 6412020.

642 37. IBGE. Pesquisa Nacional por Amostra de Domicílios Contínua (PNAD Contínua). Rio 643 de Janeiro: Brazilian Institute of Geography and Statistic; 2020.

644 38. Editorial. COVID-19 in Brazil: "So what?". Lancet. 2020;395(10235):1. doi:

645 10.1016/S0140-6736(20)31095-3.

646

647

648

649

650

651

652

653

654

655

656

657

658

659

660

661 
medRxiv preprint doi: https://doi.org/10.1101/2020.06.02.20120220; this version posted June 5, 2020. The copyright holder for this preprint (which was not certified by peer review) is the author/funder, who has granted medRxiv a license to display the preprint in perpetuity. All rights reserved. No reuse allowed without permission.

S1 Figure. (A) Incidence rate of COVID-19 on 22 May 2020, (B) Percentage of inadequate water supply and sewerage, (C) Social Vulnerability Index (SVI), and (D) Human Development Index (HDI) in the Brazilian federative units. Figure B, C and D show federative units in decreasing order of COVID-19 incidence, according to data from 22 May 2020 (A). Lines in Figure 1C represents values of SVI classified as very low (0 to 0.200$)$, low (0.201 to 0.300$)$, medium (0.301 to 0.400$)$, high (0.401 to 0.500 ), and very high (0.501 to 1$)$ [22]. Lines in Figure 1D represents values of HDI classified as very high ( $\geq 0.800)$, high $(0.700$ to 0.799$)$, medium $(0.550$ to 0.699$)$ and low $(<0.550)$ [21]. AC, Acre; AL, Alagoas; AP, Amapá; AM, Amazonas; BA, Bahia; CE, Ceará; DF, Distrito Federal; ES, Espírito Santos; GO, Goiás; MA, Maranhão; MT, Mato Grosso; MS, Mato Grosso do Sul; MG, Minas Gerais; PA, 
medRxiv preprint doi: https://doi.org/10.1101/2020.06.02.20120220; this version posted June 5, 2020. The copyright holder for this preprint (which was not certified by peer review) is the author/funder, who has granted medRxiv a license to display the preprint in perpetuity. All rights reserved. No reuse allowed without permission.

706

707

708

709

710

711

712

713

714

715

716

717

718

719

720

721

722

723

724

725

726

727

728

729

730

731

732

733

734

735

736

737

738

739

740

741

742

743

744

745

746

747
S2 Figure. Increase in cases over a period of 16 days in April, using the ratio between incidences per 100,000 on 30 and 14 April 2020. B. Chi-square test. C and D.

Likelihood ratio. AC: Acre, AL: Alagoas, AP: Amapá, AM: Amazonas, BA: Bahia, CE: Ceará, DF: Distrito Federal, ES: Espírito Santos, GO: Goiás, MA: Maranhão, MT: Mato Grosso, MS: Mato Grosso do Sul, MG: Minas Gerais, PA: Pará, PB: Paraíba, PR: Paraná, PE: Pernambuco, PI: Piauí, RJ: Rio de Janeiro, RN: Rio Grande do Norte, RS: Rio Grande do Sul, RO: Rondônia, RR: Roraima, SC: Santa Catarina, SP: São Paulo, SE: Sergipe, TO: Tocantins. 
A

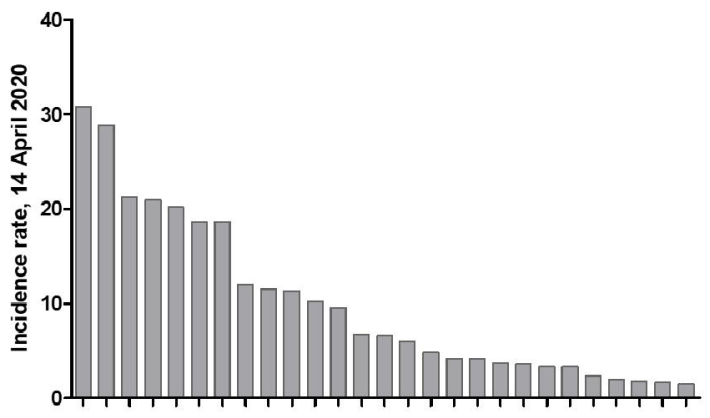

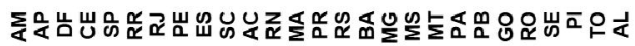
Federative units of Brazil

C

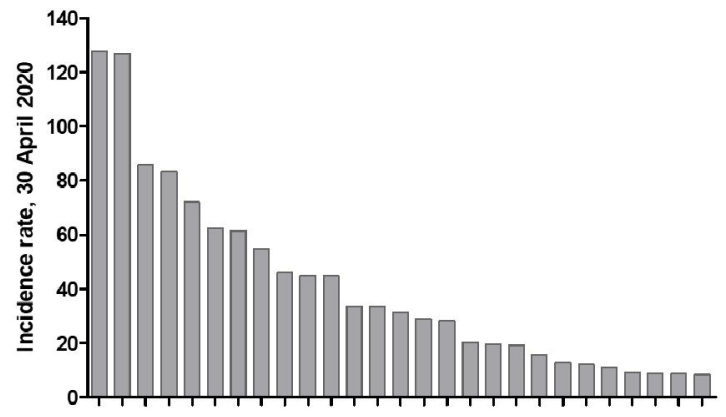

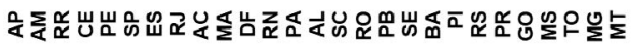
Federative units of Brazil

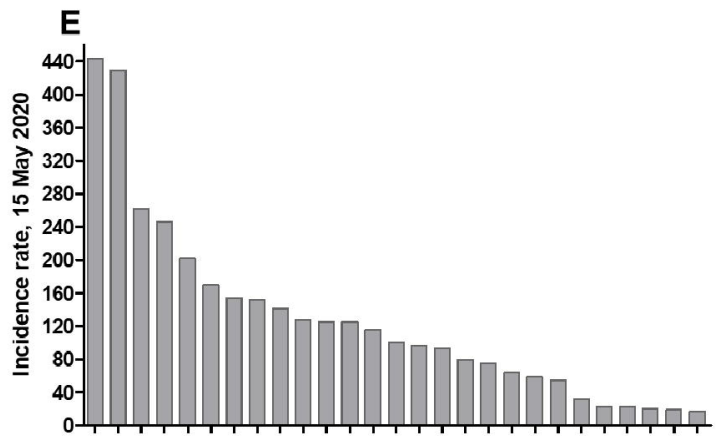

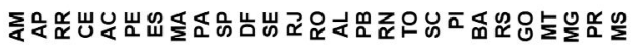
Federative units of Brazil

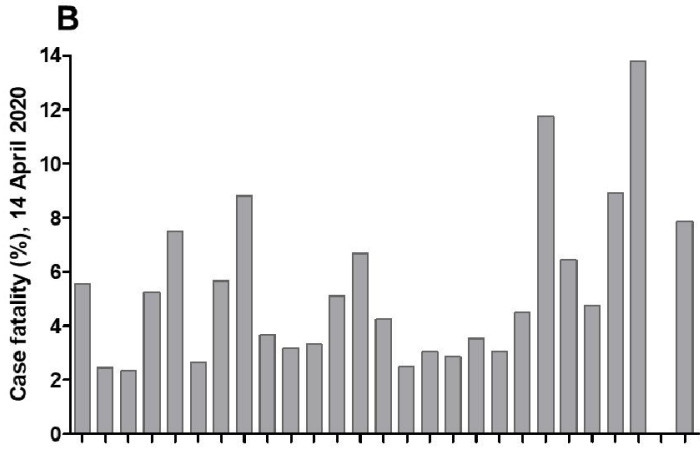

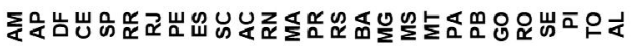
Federative units of Brazil

D

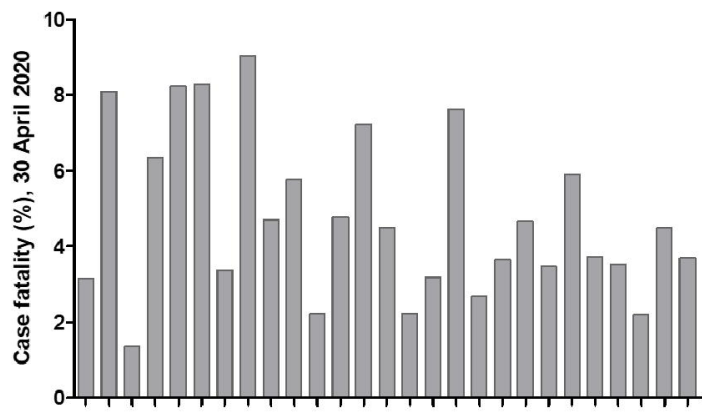

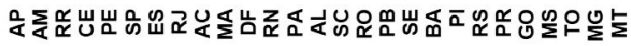
Federative units of Brazil

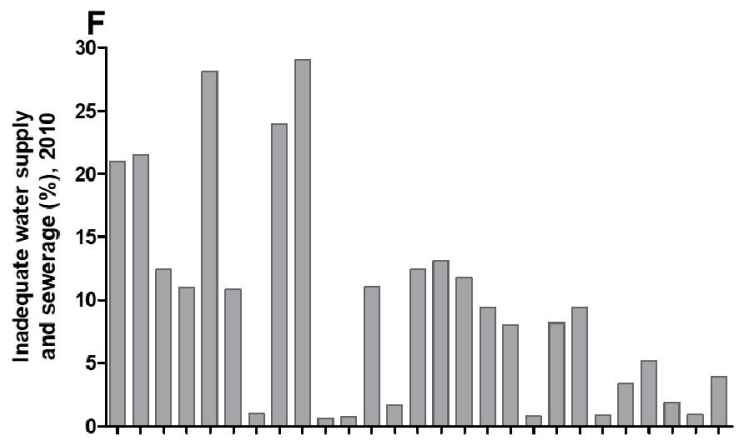

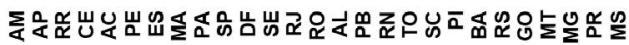
Federative units of Brazil 


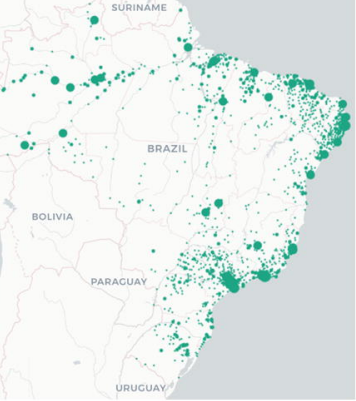

Rondōnia
Acre
Arnazonas
Roraima
Pará
Amapá
Tocantins
Maranhão
Piauí
Ceará
Rio Grande do Norte
Paraiba
Pemambuco
Alagoas
Sergipe
Bahia
Minas Gerais
Espirito do Santo
Rio de Janeiro
São Paulo
Paraná
Santa Catanna
Rio Grande do Sul
Mato Grosso do Sul
Mato Grosso
Goiás
Distrito Federal

$2,774 \quad 156.09$

$3,343 \quad 379.05$

$27,038 \quad 652.37$

$2,306 \quad 380.68$

$21.469 \quad 249.56$

$5.655 \quad 668.65$

$2,205 \quad 140.19$

$17,212 \quad 243.27$

$3.074 \quad 93.91$

$34.573 \quad 378.59$

$4.251 \quad 121.22$

$6,882 \quad 171.27$

$25.760 \quad 269.54$

$5,302 \quad 158.67$

$4.922 \quad 214.12$

$12,557 \quad 84.43$

$5,995 \quad 28.32$

$9.520 \quad 236.9$

$33.589 \quad 194.55$

$76,871 \quad 167.41$

$2,939 \quad 25.70$

$6,458 \quad 90.14$

$5.918 \quad 5202$

$805 \quad 28.97$

$1,220 \quad 35.01$

$2,304 \quad 32.83$

$5,948 \quad 197.26$
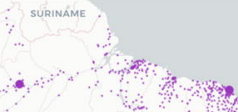

a) 1

PERU
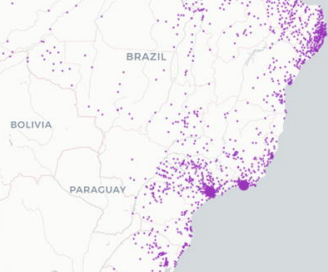

Deaths and case-fatality (\%)

$\begin{array}{lrr}\text { Rondônia } & 106 & 3.82 \\ \text { Acre } & 80 & 2.39 \\ \text { Amazonas } & 1.669 & 6.17 \\ \text { Roraima } & 83 & 3.60 \\ \text { Pará } & 1.937 & 9.02 \\ \text { Amapá } & 157 & 2.78 \\ \text { Tocantins } & 49 & 2.22 \\ \text { Maranhão } & 693 & 4.03 \\ \text { Piaui } & 93 & 3.03 \\ \text { Ceará } & 2.251 & 6.51 \\ \text { Rio Grande do Norte } & 181 & 4.26 \\ \text { Paraf̂ba } & 248 & 3.60 \\ \text { Pernambuco } & 2.057 & 7.99 \\ \text { Alagoas } & 280 & 5.28 \\ \text { Sergipe } & 82 & 1.67 \\ \text { Gahia } & 399 & 3.18 \\ \text { Minas Gerais } & 201 & 3.35 \\ \text { Espinto do Santo } & 397 & 4.17 \\ \text { Rio de Janeiro } & 3.657 & 10.89 \\ \text { SäoPaulo } & 5.773 & 7.51 \\ \text { Paraná } & 146 & 4.97 \\ \text { Santa Catarina } & 100 & 1.55 \\ \text { Rio Grande do Sul } & 172 & 2.91 \\ \text { Mato Grosso do Sul } & 17 & 2.11 \\ \text { Mato Grosso } & 37 & 3.03 \\ \text { Goiás } & 93 & 4.04 \\ \text { Distrito Federal } & 90 & 1.51\end{array}$




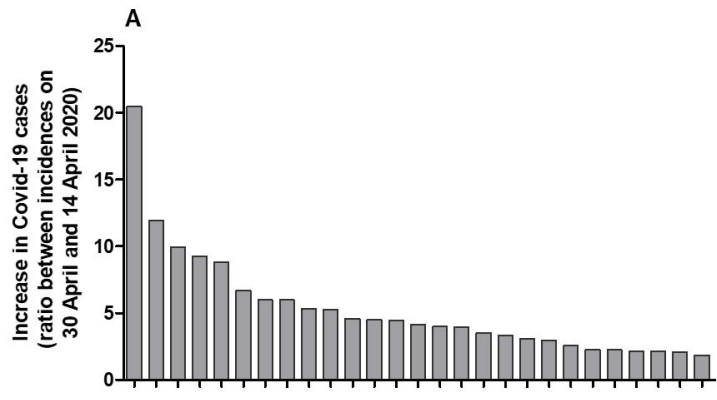

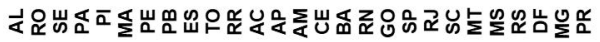
Federation units of Brazil

C

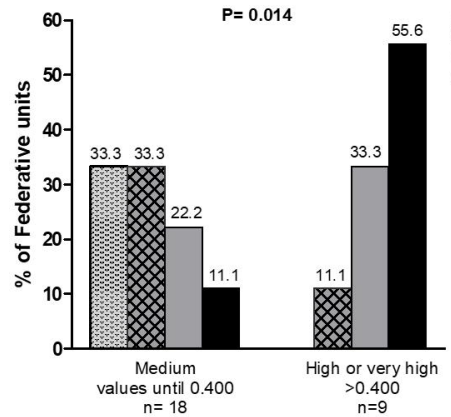

Social Vulnerability Index
Quartiles of increase in the incidence of COVID-19

(ratio between incidences

on April 30 and April 14)

1.86 to 2.55

[XX] 2.56 to 4.11

$\square .12$ to 5.99

6.00 to 20.5

Columns from left to right:

1. PR, MG, DF RS, MS, MT 2. SC, RJ, SP, GO, RN, CE 3. RR, TO, ES, PB

4. $\mathrm{SE}, \mathrm{RO}$

6. AM, AP, AC
7. $P E, M A, P I, P A, A L$

OR: 5.63

95\% Cl: 1.08 - 29.37

$\mathrm{P}=0.041$

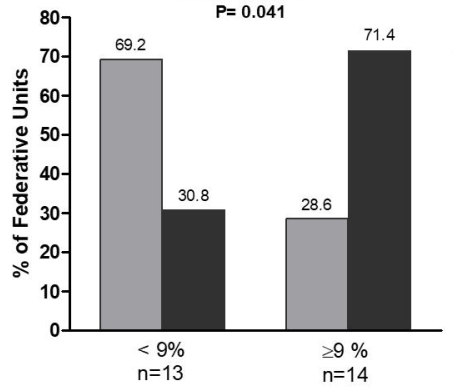

Incidence on 30 April 2020

$\square<30$

$\geq 30$

Columns from loft to right:

1. MT, MG, TO, MS, GO PR RS, PI, SO

2. DF, RJ, ES, SP

BA, SE, PB, RO

4. AL, PA, RN, MA, AC, PE, CE, RR, AM, AP

Inadequate water supply and sewerage

\section{D}

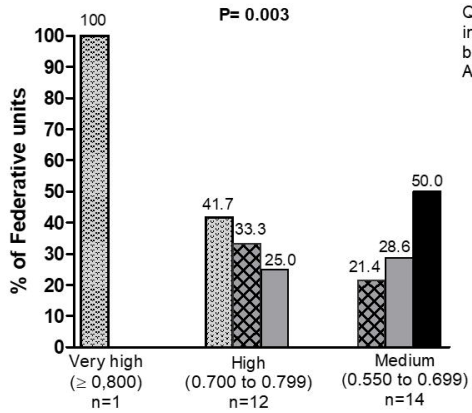

Quartiles of increase in the incidence of COVID (ratio between incidences on April 30 and April 14)

1.86 to 2.55

[XX 2.56 to 4.11

$\square .12$ to 5.99

6.00 to 20.5

Columns from left to right

1. DF

. PR, MG, RS, MS, MT

3. SC, RJ, SP, GO

4. AP, RR, ES

. RM, AC, TO $P B$

7. $\mathrm{PE}, \mathrm{MA}, \mathrm{PI}, \mathrm{PA}, \mathrm{SE}, \mathrm{RO}, \mathrm{AL}$ 